have been given to the handle, discharges sparks freely. If the two main conductors are respectively joined to the inner and outer coatings of a large Leyden jar, the discharges take place with short, loud sparks of great brilliancy. If from any cause the machine does not at once charge itself, a gentle rub with a silk handkerchief on either of the ebonite pillars will suffice to provide the requisite stimulus. The Wimshurst machine appears to be less liable than any other influence-machine to have the polarity of its charge reversed. It serves admirably for the production of the electric shadows discovered by Holtz and Righi. Mr. Wimshurst is much to be congratulated on the service he has rendered to experimental science in devising so useful and efficient an instrument.

\section{THE ZENI NARRATIVE 1}

THERE is no greater puzzle in geographical literature than the so-called "Zeni narrative" which was published at Venice in $\mathbf{1} 558$ by Francesco Marcolini, and claimed to be an authentic compilation by Nicolo Zeno of letters, in the possession of his family, which had been written at the close of the fourteenth century by two of his ancestors, the brothers Antonio and Nicolo Zeno, describing their adventures in the far north.

The story told by Nicolo Zeno was that when a boy he had found these letters in his father's palace, together with a map illustrating the travels of the Zeni brothers, and not knowing their value had torn many of them up. When he grew older he had however learnt to appreciate their true character, for like the rest of his family, one of the most illustrious in Venice, he was an accomplished scholar, and well acquainted with the results of geographical research. And collecting together all the letters that had escaped destruction, he compiled his narrative, and made a copy of the map, supplying from his own knowledge, and his interpretation of the travels of his ancestors, such names and other details as had become illegible from the then half-rotten condition of the original chart.

Ruscelli in $156 \mathrm{I}$, and Moletius, one of the editors of Ramusio, in 1562, followed by the Venetian geographers generally, believed in the authenticity of the Zeni travels, as told by Nicolo the younger, who, as a Member of the Council of Ten, occupied one of the highest posts in the Republic, and was esteemed as a liberal patron of learning. But in other countries doubts were entertained in regard to the truth of the narrative, while in some quarters there arose an utterly untenable notion, that the book had been compiled with the object of securing to Venice the honour of having discovered the New World before Columbus set foot on it. In 1595 the Flemish geographer, G. Mercator, appeared as the first among many northern writers worthy of respect who refused to see in the story told by $\mathrm{Nicolo}$ Zeno anything more than a clever forgery. One of the latest, and probably the most formidable, of these detractors, was Admiral Zahrtmann, late Hydrographer to the Danish Admiralty. As an experienced seaman, an accomplished geographer, and a Dane well versed in the maritime history of the Danish Colonies with which he had long been intimately acquainted, he was eminently qualified to judge of the accuracy of a narrative, which professed to describe a voyage among islands and to regions, which the friends and foes of Zeno are alike agreed in believing we must recognise as the Faroe Isles, Iceland, and the eastern shores of Greenland. The substance of his careful analysis of the Zeni narrative, and of the map which accompanied it, was communicated in 1836 to the London Geographical Society, in the fifth volume of whose Journal it was subsequently published. And there, is no doubt that notwithstanding

I "Studier och Forskningar, Föranledda af Mina Resor i Hogga Norden; Ett Populärt Vetenskapligt Bihang til Vegas Färd kring Asien og Europa." A. E. Nordenskjöld. Häft $x$. (Stockholm, r883.) the evidence that had been advanced in favour of the Zeni voyages by Hakluyt in 1600 , and still more emphatically a century ago by Capt. Cook's companion, George Forster, English geographers allowed themselves to be powerfully influenced by the opinions of Zahrtmann. In our day, however, the tide of public favour has changed both abroad and in England. And in addition to the uncompromising testimony to the bonâ fide character and the general accuracy of the Zeno story, borne by Mr. R. H. Major in his edition for the Hakluyt Society, in I873, of the "Voyages of the Zeni," and by M. G. Gravier in his "Découverte de l'Amérique par les Normands au roème Siècle," 1874, there is now the allpowerful evidence of Baron von Nordenskjöld to be adduced as corroborative, and seemingly conclusive, proof of the genuineness of this mysterious, and longquestioned story of early Venetian adventure in the northern seas.

While engaged in drawing up a history of north-eastern exploration for his "Voyage of the Vega," Nordenskjöld's attention was directed to the story of the Zeni voyages, of which he gives a Swedish translation in the number before us of the Studier och Forskningar, together with the result of his analysis of the narrative, and his comparison of the Zeno map with all the printed and manuscript maps known at the time of Marcolini's publication in 1558 Among the numerous interesting conclusions at which he has arrived, special attention is due to the following:-(I) That the general accuracy of the descriptions, for which there was no other known source, proves that the Zeni brothers must have been personally acquainted with the Faroe group and the other islands described in the marrative, as well as with the eastern shores of Greenland; and (2) that, considering the nature of the details given of the mode of life followed by the savages in regions lying in the north-west of the Atlantic, which are now known to us as Newfoundland, Canada, and the United States, but of which European; had no correct information until the colonisation of those lands in the seventeenth and eighteenth centuries, there is every reason to believe that the Venetian travellers conversed, as they assert, with persons who had visited these districts of the New World. Further, Baron von Nordenskjöld is of opinion that in the descriptions given by the Zeni's informants of the civilised communities, which they met with during their prolonged wanderings in these unknown western lands, we have evidence of the influence and persistence up to the close of the fourteenth century, when the Zeni are assumed to have been in the north, of the earlier Scandinavian colonies, which undoubtedly existed in the New World in the tenth and eleventh centuries.

The author shows that in the middle of the sixteenth century there were three maps in use, of the north and of the north-west, which, in addition to the Zeno map, had all been derived from northern sources, preceding the date of the discovery of America by Columbus. Of these the most important is a manuscript map, with descriptions of Northern Europe and of neighbouring lands, bearing the date of 1427 , on which the Scandinavian countries are for the first time set down with anything like accuracy, and a considerable part of America is delineated. Our knowledge of this important pre-Columbian chart is entirely due to Baron von Nordenskjöld, who discovered it in a manuscript copy of Ptolemy's "Cosmographia," pre:erved in the Town Library of Nancy, of which he was permitted to make a facsimile, and to give a photographic copy in his Studier och Forskningar.

The value of this curious record of the geographical knowledge possessed in the early part of the fifteenth century of Scandinavia, and the adjoining seas, is increased by the fact that the map was laid down by a native of the Danish Island of Fyen, known as Claudius Clavus, or Cimbricus, who undertook the task for and 
at the instigation of the learned Cardinal, Gulielmus Filiastrus. Claudius' map, which is brightly coloured, and well supplied with the names and geographical determinations of places, ends at $74^{\circ} \mathrm{N}$. lat., and begins at $55^{\circ} \mathrm{N}$. lat., in which meridian a line is drawn through England, Holsatia (Holstein), and Pomerania, thus taking in the whole of the Baltic, whose islands and shores from the then Danish province of Halland, in Scandinavia, to the Gulf of Finland, are laid down with a fair amount of accuracy. In the far west we see Grönlandia, while on the shores of the Arctic Sea, named here "tenebrosum mare," we have at the very north of Scandinavia "Engrönuelandi," which would appear to have been an old designation of part of Finmark, and possibly the region from which Grönland derived its name.

In all respects the chart drawn by C. Clavus in 1427 is so far superior to the Donis map, printed at Ulm in I482, which had formed the basis of Bordone's, and many other later maps, that, as Nordenskjöld points out, it must have been based on independent sources derived from the actual experience of seafaring observers. As, moreover, the Zeno map corresponds far more closely with the Clavus than with the Donis chart, with whose errors of position and distortions of outline it has little or nothing in common, there is not the slightest ground for asserting that the Benedictine monk, Nicolaus Donis, whose atlas is a mere copy of drawings to be found in the mediæval manuscripts of Ptolemy, was the authority from whom the younger Zeno derived his acquaintance with the far north, in which he included East Greenland and NorthWest America. We have no space to enter more fully into the interesting details with which Baron von Nordenskjöld supports his argument in favour of the authenticity of the Zeni narrative. But in conclusion we must draw attention to the success and ingenuity with which he has shown, that the often-sought-for and much-talked-of manuscript map of the north, which Admiral Zahrtmann saw in the University Library at Copenhagen, and declared to be the undoubted original from which Zeno's map had been derived, was simply a copy of Donis's chart. This fact he has so conclusively established, that henceforth Zahrtmann's charge against Zeno the younger must be considered to have lost one of its strongest supports; while future commentators on the Zeni voyages need no longer scour the libraries of Northern Europe in quest of a phantom map, whose disappearance soon after it had been seen by Zahrtmann has largely contributed to the tardy solution of the Zeno mystery.

\section{NOTES}

THE following awards will be made at the anniversary meeting of the Royal Geographical Society on the 28 th inst. :-Founder's Medal to Sir Joseph Dalton Hooker, F.R.S., for his eminent services to scientific geography, extending through a long series of years and over a large portion of the globe, while engaged in voyages in the Antarctic and Australian Seac, and journeys in India and the Himalaya, in Morocco, and in the United States of America; and more especially for his long-continued researches in botanical geography, which have thrown light on the form of the land in prehistoric times, and on the causes of the present distribution of the various forms of vegetable life on the earth. Patron's Medal to E. Colborne Baber, Chinese Secretary of Legation, Peking, in recognition of the great value of his scientific work, chiefly geographical, during many exploratory journeys in the interior of China ; and for his reports of these journeys, drawn up with admirable skill, accuracy, and completeness, which he presented to the Society, and which have been published, together with route maps engraved from his own finished drawings, in the first part of the "Supplementary Papers." The Murchison Grant for 1883 to Wm. Deans Cowan for his extensive surveys in the Tanala, Betsileo, and Bara provinces of Central
Madagascar, an account"of which was read by him to the Society in June, 1882, and published in the September number of the Proceedings of the same year; also as an encouragement to him in the new journey of exploration he is about to undertake in Western Madagascar. The Back Grant for 1883 to the Abbé Petitot for his geographical and ethnographical researches in the region of the great lakes of the Arctic basin, between Great Slave Lake and the Polar Sea, and his map of the basin of the Mackenzie. The Cuthbert Peek Grant for 1883 to F. C. Selous in acknowledgment of the value of his gengraphical researches in South Central Africa, including a journey in 1877 through the Manica country, north of the Zambesi, an examination of the hydrographical system of the Chobe, and two journeys by previously untrodden routes through Mashonaland, carefully prepared maps of which he communicated to the Society; also as an encouragement to him in the further researches in geography and natural history he has undertaken in the same region. The following will be elected as honorary corresponding members : Duca di Sermoneta (Prince Teano), president of the Italian Geographical Society, and of the International Geographical Congress at Venice, I88I ; Dr. Schweinfurth, the eminent African traveller, now resident at Cairo; Edwin R. Heath, M.D., the explorer of the Beni River, South America, now reșiding at Wyandotte, Kansas, United States.

THE annual soirée of the Royal Society was held on the $25^{\text {th }}$ ult. in the absence of the President, on account of indisposition. Among the recent scientific work illustrated was a photograph of the nebula in Orion, exhibited by Mr. A. A. Common, which is certainly one of the most interesting astronomical photographs which has ever been taken. We may also mention an interesting exhibit by Mr. W. Gall sway, exemplifying the effects of coaldust in colliery explosions, and "The Firedamp Cap," a phenomenon seen in mines. The only other exhibit of real general interest were some garlands from the tombs of Rameses II. and other kings, whose mummies were recently found at Thebes. Many of our readers have doubtless seen tbem in Egypt at the famous Boolak Museum, but those who have not done so must thank Dr. Schweinfurth for sending them over to Sir Joseph Hooker, and Sir Joseph Hooker for exhibiting them. These garlands are chiefly formed of leaves of Mimusops Schimperi, and petals of Nymphrea carulea and Lotus sewn together with fibres of date-leaf; others of the leaves of Salix safraf, with pods and flowers of Acacia Nilotica, Sesbania Egyptiaca, and Carthamus tinctorius, and petals of Alcea ficifolia.

Dr. Hans GaDow has been appointed to the Strickland Curatorship in the University of Cambridge, vacated by the resignation of Mr. Salvin, F.R.S. Dr. Gadow began his biological studies under the late Prof. Peters in the University of Berlin, but graduated at Jena, whence he proceeded to Heidelberg, and worked there under Prof. Gegenbaur. Coming to England about two years ago, he was engaged, at the suggestion of Dr. Günther, by the Trustees of the British Museum to deter mine the specimens to be included in volumes viii. and ix. of their collection. The product of his labours in this direction is still in the press, but his contributions to the Fournal fïr Ornithologie, the Proceedings of the Zoological Society, and other scientific journals, show him to be one of the most promising of the ri ing generation of ornithologists. In October last Dr, Gadow was appointed to deliver a course of lectures on the Morphology of the Vertebrata in the University of Cambridge, which has given much satisfaction to all concerned.

WE regret to announce the death of Dr. Wilhelm Peters, Professor of Zoology at Berlin University, and Director of the Zoological Museum of that city. He died on April 20, aged sixty-seven. The leath is also announced of Dr. Gustav Radicke, Professor of Mathematics at Bonn University. He died at Bonn on April 18, in his seventy-third year. 